\title{
An African view of women as sexual objects as a COnCern FOR GENDER EQUALITY: A CRITICAL STUDY
}

Author:

Elijah M. Baloyi

\section{Affiliation:}

${ }^{1}$ School of Humanities and

Theology, Department

of Practical Theology,

University of South Africa,

South Africa

\section{Correspondence to:}

Elijah Baloyi

email:

baloye@unisa.ac.za

Postal address:

Department of Practical

Theology, University of

South Africa, PO Box 392,

UNISA 0003, South Africa

\section{Keywords:}

gender equality; sexual

objects; clitoridectomy;

rape; lust

\section{Dates:}

Received: 04 Mar. 2010

Accepted: 13 Aug. 2010

Published: 17 Nov. 2010

How to cite this article: Baloyi, E., 2010, 'An African view of women as sexual objects as a concern for gender equality: A critical study', Verbum et Ecclesia 31(1), Art. \#380, 6 pages. DOI:10.4102/ve.v31i1.380

\section{This article is available} at:

http://www.ve.org.za (c) 2010. The Authors. Licensee: OpenJournals Publishing. This work is licensed under the

Creative Commons

Attribution License.

\section{ABSTRACT}

South African society consists of people who value honour, respect and dignity. One of the most worrying factors in our democratic country is the escalation of sex-related violations like rape, sexual harassment and sexual abuse. According to media reports, the rape and abuse of women are daily occurrences. Statistics also suggest that most marriages will at some point need to resolve the emotional trauma resulting from an extra-marital affair. It is imperative that whilst the police are trying to get the culprits into custody, we as a society should help to find out what has gone so wrong that the beautiful gift of a sexual relationship is being abused and degraded by the people. This delicate issue may be an indication of the influence of patriarchal systems in some African cultures. Rape statistics reveal that most of the perpetrators are well-known members of a community. There are many possible reasons why our society is facing this challenge; however, this study will explore the view that women are considered as sexual objects and how this perspective reveals itself as the cause of sexual offences.

\section{INTRODUCTION}

Lopez writes that:

Women are sex. A man wants what a woman has - sex. He can steal it (by rape), persuade her to give it away by seduction, rent it through prostitution, lease it over a long term through marriage, or own it outright by marriage in most communities.

(Lopez quoted in Baloyi 2009:109)

The above quotation reminds us of the plight faced by women and girls living in a patriarchal world. Although the hegemony of female oppression and gender inequality is as old as patriarchy itself, the democratically elected government is attempting to find solutions to the negative consequences caused by these acts of discrimination, such as the establishment of the Commission for Gender Equality and other stakeholders.

It may be argued that the responsibility to protect women and to ensure that they are given their rightful place in society should not fall at the feet of the Commission for Gender Equality alone, but that the nation as a whole should become involved in this cause. One of the ways in which this can be achieved is through the elimination of sexual offences, which are encouraged by the perception that women are mere sexual objects. It is therefore the aim of this study to argue that viewing women as mere sexual objects is one of the reasons why sexual immorality, witnessed as rape, prostitution and teenage pregnancy, is escalating.

According to Waruta and Kinoti (2000:109), African societies had their own ways of regulating sexual relationships by observing very definite taboos and rules (e.g. emphasising that bride wealth should be given before marriage takes place), whilst at the same time, providing socially acceptable avenues for growing persons. Waruta and Kinoti go on to say that sexual immorality, like fornication and rape within some Christian communities, are prevalent even though they are dealt with harshly. I concur with the two scholars in saying that '[P]rostitution and teenage pregnancies continue to escalate in areas supposedly predominantly Christian, demonstrating the general failure of Christian sexual morality'. Masenya (2003) argues that sexual immorality is worsened by the fact that men and women have been conditioned to believe that sex is mostly enjoyable for women when it is painful. She states that:

It becomes understandable that male-oriented societies have a tendency to confuse or even equate sexual activity with sexual violence. It is even more disturbing for religious communities, that some sections of the sacred scriptures are interpreted to support sexual violence against women and children. Women's sexuality is often defined and controlled by men both in the churches and in the households. Female bodies become sacrifices at the altars of male power and pleasure.

(Masenya 2003:102)

This argument is endorsed by Lebacqz (1998:72) who asserts that although sexual arousal may follow biological patterns, what we find sexually arousing is not only culturally influenced, but socially constructed as well. These arguments not only make the study of the manner in which men view women as sexual objects a relevant one, but also indicate the importance of dealing with this view and the stigma attached to it. The study also underlines the contribution this particular view of women has made to the acceleration of abuse of women, both culturally and traditionally.

This study will grapple with information related to the sexual objectification of women from an African perspective. The literature consulted comprises (African) books on the subject, newspapers and other media reports. It will be necessary to evaluate the findings in the light of the Bible and African tradition. 


\section{PROBLEM STATEMENT AND RELEVANCE OF THE STUDY}

Groothuis is of the opinion that ' $[\mathrm{N}]$ ow more than ever, a woman is a pawn in a man's world, a sex object whose use is dictated by the male rules of the sexual game' (Groothuis 1994:77). Our media (newspapers, radio stations, TV and other means of media) indicate that sexual immorality is one of the fastest growing misdeeds in South Africa. The Commission on Gender Equality (CGE), for instance, received many complaints from South African citizens about advertisements that portray women as sex objects (Mpumelelo 2005:8) and elicits concern from academic authors such as Elisabet Le Roux (2009:1). Le Roux mentions that the South African Broadcasting Corporation $(\mathrm{SABC})$ should respect the allocated times for the screening of sexual matters, which can also be harmful to women and children; she argues that '[T]he South African government is making it clear that they believe that exposure of children to pornography is a growing and very worrying issue' (Le Roux 2009:1).

A report carried on SABC news made a mention of a 14-yearold girl who has been gang-raped by ten boys in Katlehong and that four boys had raped a girl with a video camera recording the incident in another area in the same municipal area. This introduces the reader to a problem wherein sexual immorality is instigated by lust and creates an unfortunate situation in the community. The Deputy Minister of Home Affairs, Malusi Gigaba, echoed a similar sentiment:

There is a growing demand to protect children from sexual exploitation as well as from exposure to illicit material. It is important that we should try to accumulate as much information as possible about the crime of child pornography, the threat of technology to children as well as the exposure of pornography to women. We must not delude ourselves: staggering numbers of children in South Africa are at risk of being exposed to illicit material.

(Gigaba 2008)

This quotation indicates that our government is not only concerned by the viewing of women as sexual objects, but it is also becoming more involved in trying to fight this view of women.

Masenya (2005:188) holds the opinion that 1 Corinthians 7 is usually cited to remind women that they must always be available for the sexual gratification of their spouses. Manala (2005:901) says that gender insensitivity towards and oppression of women and children manifest in various forms of abuse, including cruel acts of sexual violence in many South African communities. These views opened my mind to reflect on how patriarchy naturalises and eroticises female violence, a situation that is reinforced and perpetuated by the African patriarchal system and andro-centric biblical interpretations common in our cultural settings. The violation of women's bodies in African tradition is a cause for great concern, especially when contemporary society is striving to retain its dignity and honour.

African cultures not only endorse the view that women should be regarded as objects of sexual fulfilment, but also encourage men to see women in this light and can be witnessed in the way children are raised, through the treatment women receive and the rituals performed in the community (Baloyi 2009:115). Some men see women as sexual objects and even force them to have sexual intercourse to get jobs whilst other women are exploited sexually for job promotions. In one case study an account is given of a marriage that was dissolved after the husband found out that his wife was involved in sexual intercourse with the company manager as a condition for employment (Baloyi 2009:117).

King (1989:28) says that sexism refers to any kind of subordination or the devaluation of a person or group solely on the grounds of sex. It is the aim of this article to highlight the fact that women are being devalued by being viewed by some men as mere sex objects. The growing statistics on people with HIV or AIDS is a reflection of where we fall short in critically evaluating the view of women as sexual objects in this respect. Despite all this, one may ask how women can be abused sexually as objects when God allowed marriages (in which sexual intercourse is not only permitted, but also important) to take place? When reading on how men see women as sex objects, one has to agree with Louw (2009:103), who says that we cannot separate sexuality from selfesteem, communication and love.

Mbiti (1991:135) states that although it is often difficult for parents to impart sexual knowledge to children, girls are 'better off' in this respect than boys, because they spend more time with their mothers and with older women than boys do. The fact that many men expect women to respond to their immediate need for sex is another reflection of the fact that the status of women has been reduced and lowered to that of mere sex objects (Baloyi 2009:108)

\section{THE VIEW OF WOMAN AS AN OBJECT FOR MAN}

\section{Women as seen in the wrong light}

Groothuis (1994) writes that:

Feminists who advocate sexual freedom for women as well as men are simply playing into the hands of those men who seek irresponsible sex with any woman who is momentarily desirable. Now, women are still sex objects, they are simply more available than they used to be.

(Groothuis 1994:76)

This statement not only indicates to what extent women are becoming sexual objects but also serves as a justification for my study which contends that men's view of women as sexual objects is a cause for concern for the morality of African people in this country.

The context within which the issue at stake will be discussed is an African situation where male domination and superiority along with female submission and inferiority are perpetuated by patriarchy. It is within this context that systemic violence is not only naturalised, but also normalised. Even if some women may not have experienced the violation of their bodies by men in one way or another, women and girl children live with this fear for their entire lives, for the sake of the system (Masenya 2003:99). The gist of the matter is that in traditional African society, women were looked upon as perpetually dependent beings who always had to be directed and protected by men. They are objects of use, abuse and exploitation and a source of wealth to men, who consider them personal property (Mugambi \& Magesa 1990:61).

African people did not discuss issues related to sex openly, which does not necessarily mean that they disliked it, but it was taboo to talk about it openly because this was regarded as bedroom talk. In support of this view, Mugambi and Magesa (1990) say:

In African traditional society, it was taboo for a parent and a child to talk about sex and other related issues, but times are changing and this attitude should also change accordingly.

(Mugambi \& Magesa 1990:78)

Marriage, according to African thinking, is the only channel for full sexual expression. Seeing as sex is considered 'normal' only within the context of marriage, men who experience a desire for sex, need a permanent partner for full expression of this desire. The reason for this is that, whilst sex is possible without marriage, it would be sex without meaning (Kimathi 1994:44). Sex and marriage in an African context are inseparable. For this reason, marriage and procreation were never left to the individual in traditional African society, but the intervention of 
family clans in married life was always common because the family would expect to see children born. This naturally had either direct or indirect consequences for the sexual life of the couple (Waruta \& Kinoti 2000:114)

According to Kimathi (1994:14), Trobisch described an unmarried African woman as a garden without an owner. A man is compared to a gardener, for he claims the garden and sows his seed. Whilst one man can have several gardens, a garden can have only one owner. This clearly indicates that men are regarded as subjects whilst women are perceived as passive objects. The issue of sowing the seed is used to interpret the question of bearing children, which is closely related to sexual intercourse, because man is portrayed as the active participant who plants the seed whilst the woman is portrayed passive recipient. This portrait corresponds to the one in the Code Napoleon, as quoted by Groothuis (1994):

Woman is given to man to bear children, she is therefore his property, as the tree is the gardener's. Before twentieth century studies in biology informed men otherwise, the widespread conviction which served patriarchal purposes well, was that a woman's role in reproduction was merely to provide very good soil in which the male seed could be planted. The male is assumed to possess a sort of generic human identity, whereas the female has more of a sexual identity (probably because her primary function is seen to be her role in sexual reproduction).

(Groothuis 1994:33)

This attitude projects women as passive recipients of men, which, in turn, makes them direct objects of men. According to Kimathi (1994:14), this concept illustrates why men are judged more leniently for the sin of adultery than women. That is why Masenya (2003:102) argues that male privilege, reinforced by systemic patriarchal structures, enables males to take delight in the violation of females.

In order to emphasise that many men view women as sexual objects, Trobisch states the following:

A boy whose first stirrings of sexual arousal came in the context of seeing women's underwear may thereafter call up the image of woman's underwear whenever he wants to re-evoke the original rush and in order to aid masturbation.

(Baloyi 2009:115)

Readers should also understand that in African tradition, sexual intercourse was not expected to be a long-life practice for women. When a woman enters menopause, she is no longer considered suitable to have sex. The husband, on the other hand, could get a younger woman as second wife for the purpose of sexual intercourse, if he so wished. Kyomo and Selvan (2004) assert that:

In many ethnic groups there is an understanding that a woman is not allowed to have sexual intercourse after the menopause. It is believed that as a first symptom that the stomach of the woman acting against the taboo (of having sexual intercourse after menopause) will grow bigger and bigger.

(Kyomo \& Selvan 2004:35-36)

The sole reason for barring women from sexual activities once menopause has occurred is that the main purpose behind engaging in sexual intercourse with women was to bear children. A woman was also prohibited from having intercourse as soon as her children bore children and she became a grandmother. According to Kofon (1992:158), seeing that marriage was mainly intended for childbearing, it was believed that when grandchildren were born, the grandmother would no longer be sexually active and hence she would be rested; the second wife would be married for sexual purposes.

One of the aims of African parents raising girls is that they will get married and have sexual intercourse with their husbands. The traditional rituals performed on the bodies of young girls assisted in teaching them how to behave sexually. Although some of these rituals were not common to every African tribe and considering the fact that some are no longer practiced, it is good to highlight these rituals to aid understanding in terms of the background of how African people orchestrated the perceived view of African females in history. One ritual is called clitoridectomy. Here the clitoris is removed and the vagina sewn up (infibulation) in order to prevent the girls from having sexual intercourse before marriage (Waruta \& Kinoti 2000:142). Metuh (1987) writes as follows:

During the first phase the girl undergoes clitoridectomy. After the wound is healed, the girl may be let out for two months, and then is readmitted for the second phase during which a full-scale fattening takes place. When the clitoris is cut, the fallen piece is dried and inserted into a dried fish and given to her future husband to eat. There was a belief that any husband who eats the excised part of the clitoris of his virgin wife would always love her and their marriage would last as long as they both lived. Clitoridectomy for the girl was also used to check her desire for other men, and make her faithful to her husband.

(Metuh 1987:209)

This practice was performed on girls when they reached a certain maturity stage as an attempt to prevent them from performing sexual acts before they enter marriage. Clitoridectomy was not practiced by all African people, but for the sake of this study a mention of this practice will help to broaden the concept of viewing of women as objects.

\section{The reasons for seeing women as objects}

The reason for practising clitoridectomy is that the assumption exists that girls should still be virgins when they marry. According to the practitioners, performing a clitoridectomy would ensure that a girl is still a virgin seeing that her vagina would be sewn until the day of her marriage. This was another way of teaching virgins how they are supposed to please their husbands sexually when they are married. For this reason, if a girl was found to be a virgin in her wedding day, there was great rejoicing and she was praised together with her family. According to traditional African society, the point was that one should not play about with those parts of the body designated for child bearing purposes until the appropriate arrangements have been made for a marriage to take place and to be consummated. Sexual organs were and still are regarded as gates of life and should be respected as such (Mbiti 1990:146). On the other hand, if the girl was found to have lost her virginity, it was regarded as a serious matter. In certain cases, African girls were killed, whilst in less severe cases, marriages were dissolved and marriage goods were returned (Mbiti 1991: 110). In the South African context, some African girls were mocked whilst others were returned home when it was found that they were no longer virgins on their wedding day (Baloyi 2001:64).

During the sewing up of the vagina, a small opening is left for urination and it was only after the wedding ceremony that an operation was performed and the vagina cut open again so that the girl can have sexual intercourse with her husband (Thiam 1986:57-58). This is further evidence that society saw women as sexual objects and prepared girls to save their vagina for their prospective husbands. According to Baloyi (2009:120) the sole purpose of a woman is to be there for the man, for the purpose of sexual intercourse. This makes it clear that girls are dehumanised for virginity's sake whilst no one makes sure that men are virgins until they marry.

From these statements it is clear that some African societies saw women as sexual objects and prepared them to save their virginity for their husbands. This indicates that the sole purpose of a female, even when she was being raised, was to become a man's sexual object. In other words, many issues surrounding the raising of a daughter were aimed at making her sexually obedient to her husband (Baloyi 2009:120).

According to Mbiti (1990:143), there are areas where sex is used as an expression of hospitality. It was understood to be an issue 
of hospitality towards women who need to fulfil such a desire. On the other hand, if a man visits another, the custom is for the host to give his wife, daughter or sister as welcoming gesture towards the guest. That is why in cases where the husband is forced by circumstances to live away from his wife for a long time, it may be arranged for a friend (particularly a husband's brother) to have sexual intercourse with the deserted wife (Kyomo \& Selvan 2004:85). This custom is old and outdated, but there are still a few people who practice it.

Trobisch views the woman as a passive recipient even in marriage because the literal translation of the book 'I married you' (also translated into Tsonga as ndzi ku tekile) indicates that the man actively married the woman, who was passively married (Baloyi 2009:139). The fact that the emphasis is on the man marrying whilst the woman is being married traditionally makes a woman an object whilst the man is a subject. That might also be the reason why men sexually abuse their wives without the least resistance.

\section{The consequences of viewing women as sex objects for individuals and society}

It was reported in the newspaper, the Sunday Sun, that a husband residing in Bethal in Mpumalanga sent two men to fetch his wife and brought her into the forest where he was the first to rape her in front of these men. Thereafter the other two also gang-raped her before finally assaulting her and leaving her to die in the forest without any transport (Sunday Sun 24 July 2005:31). For the husband and these two men, the woman was nothing more than a sexual recipient.

During an anti-crime road show at Mukhomi, the Limpopo provincial police commissioner referred to a village outside Giyani in Limpopo where 4810 rape cases involving women and children were reported in the province in 2002 alone. $\mathrm{He}$ said: 'Just a week ago I was in Nebo where a 75-year-old woman was raped by a boy aged 25 years' (Sengani 2003: Unpublished paper). This is an indication that some men value women as mere sex givers. If sex is not given voluntarily, the men force the women to do so. A report in the media recounts the traumatic story of a minister's 13-year-old daughter being raped by a 43-year-old church elder whilst cleaning the church building (Pule 2002:4)

According to Kimathi (1994:13), a woman's part in the sexual act was confined to pleasing her husband and bearing children In the Kamba tradition (A tribe in Kenya) woman avoided sexual excitement. If she showed evidence of sexual excitement and became an active participant in the sexual act (with her husband), it was an indication to the husband that it was time he married a new wife. Therefore the sexual act was for the enjoyment and satisfaction of men only. In other words, the woman was expected to remain as passive as possible during sexual intercourse to avoid arousing the suspicions of her husband, whilst the husband enjoyed it freely without the least resistance (Kimathi 1994:14). Although the Kamba traditions cannot be used for all Africans, it helps the reader to understand that the issue of African people reducing women to sexual objects is an issue that needs attention.

Similarly, some women were beaten by their husbands to force them to offer sexual intercourse. Severe force has often been applied by men who regard women simply as sexual objects. According to Dreyer's research (2009), an interviewee said:

He forced me to have sex with him. If I said I was tired he forced me or beat me and said he paid lobola for me. I must give him anything that he wants. He said he married me for sex. So I have to do what he wants just to make him happy.

(Dreyer 2009:2)

In this context, the sexual act was performed not to please both persons, but to please the man because he is the subject whilst the wife is the object. Maluleke and Nadar (2002:14) say that practices such as lobola and dowry are entrenched and established cultural practices and expectations that disadvantage and violate women. However, I believe such a statement to be a generalisation which needs more research because the practice of lobolo does not always yield the same expectation. There is a need to also study the other positive aspects of lobolo, such as a 'token of gratitude' (Baloyi 2010:17) as part of African tradition.

The man referred to in Dreyer's research is evidence of the fact that he only married for reasons of sex, which means that if his wife fails to participate in sexual acts for some reason, the marriage becomes meaningless and might be dissolved. The importance of the sexual aspect is the most central reason for marriage. That is why when there is no longer any need for sexual activities the woman would tell her husband that it is time he looked for a new wife to perform the sexual role (Kimathi 1994:13). The traditional reason for the end of sexual relations was the menopause because that meant the end of the procreation responsibility, which formed the backbone of marriage. This is another indication that men could continue to be active in sexual intercourse whilst their wives were exempted.

Some women are sexually harassed in the workplace by people who promise them employment or promotion. According to Baloyi (2009:110) Marrie Fortune revealed a story of a woman in America. She says that one woman quit her job because a male senior co-worker begged to have sexual intercourse for the sake of securing her job. Baloyi (2001:117) indicates that the same harassment often occurs in South Africa as well. One example of this is the dissolution of a marriage after the husband found out that his wife was having sexual intercourse to gain promotion at work (Baloyi 2001:118).

One of the examples from the Bible is taken from Judges 19:24 and reads: 'Here is my virgin daughter and his concubine. I will bring them out to you now and you can use them to do them whatever you wish.' Without taking into consideration the circumstances and the cultural beliefs of this man, one could easily think that women have been doomed from biblical days to serve no other purpose than to provide sexual relief for men. It is very sad that when the virgin daughter expected to get protection from her father, the head and protector of the members of the patriarchal household, she was betrayed not by a boyfriend or a close girl friend, but by the one who had fathered her (Masenya 2003:116). This immediately suggests that men who see women as sexual objects may be handicapped by their culture and traditions, which is also the case in Africa. This is a culture in which women were subjected even regarding sexual matters. This is supported by Kyomo and Selvan (2004:85) who indicates that even the sexual taboos and restrictions were mostly one-sided, teaching women to be the objects of men.

\section{CRITICAL EVALUATION}

It is evident that there are a number of causes that contributes to males seeing females as their sexual property or objects in South Africa. It is also very clear that African culture did not invent all these causes, many of which are the result of technology. Africans can take the blame for their part of the problem, for instance clitoridectomy. Another point is that this practice was biased because it only conserved the virginity of girls, but nothing was done to men for the same reason. In this way African society demonstrated its lack of respect towards women. It is also unfair to hold women's biological appearance against them. They deserve to be treated with the same dignity as men.

Louw (2009:95) is correct to say that sexual matters must be accompanied by love in its true sense. He states: 'Sexual love is connected to biological drives. It includes the important dimension of the satisfaction of the sex drive, and eventually at some stage, intercourse.' In other words we cannot think about sexual matters if we disregard or undermine concepts 
like commitment, responsibility and trust. Any sexually related thinking must at least convey the message of trust and honesty. That will mean that the gift of sex should be abused as some people are doing today.

Louw (2009:93) argues that libertarian sexual ideology is where sex is viewed as a positive, beneficial, joyous phenomenon. He writes as follows: 'Its expression is connected to personal health, happiness, self-fulfilment, and social progress.' Although I personally do not support the libertarian sexual ideology, but the fact that if sex is used accordingly (in wedlock) it is positive and can also bring happiness and joy to those involved. In actual fact, sex in its own has nothing negative if it was used accordingly, but whether libertarian ideology should be accommodated or not will need more research to be conducted.

It is good that virginity was highly prized by our ancestors and still is up to today (Van der Walt 1998:10), but guarding it through clitoridectomy indicated a bias against women and underlined the humiliation they suffered because nothing was done to preserve virginity in men. One argument is that if this act was used to prevent girls from having sexual intercourse before they marry, certain measures should have been applied for the same reason towards boys as well. In a certain sense, the question of equality of the sexes has become a relevant one. In my opinion, Africans should have found another way to guard virginity, one that applied to males as well, instead of such a humiliating act. Though it could be argued that this action was not performed by men, socially and culturally, the act symbolises the fact that women are controlled and dominated by men (Mugambi \& Magesa 1990:64). In other words, this is an internalised and culturalised form of oppression of women.

African people must be educated to understand that sexual practice is meant for people who are married to each other. When sexual intercourse is practised outside marriage, its initial aim is violated and the consequences are unfavourable (Kofon 1992:158). De Bruyn (1993:161) argues: 'It is unfortunate that we still have women in our society who try to incite men just like Pharaoh's wife tried to do to Joseph.' This statement is not intended to smack the patriarchy in which we are living, but to indicate that even in this patriarchal society, some females try to capitalize on some male weaknesses to bring them down. It must be understood that this statement does not justify a general impression that all women expect the same treatment from men. There are women who expect sexual issues to be confined to a committed relationship.

\section{Females are also images of God}

There are many references to the image of God in the work of theologians (cf Berkhof 1988:26-31; Nyirongo 1997:107; Waruta \& Kinothi 2000:130; Masenya 2003:98-122; Mokgotho 2004:69). For the purpose and the time for this study I will not detail the different understandings and theological convictions about the concept of Image of God (Gen.1:26-27), but I will indicate the fact that God created both males and females in His image. These teachings are very important when trying to rebuild the image of women that has been damaged by those people who think that women were created only to please men sexually. Like the depiction of women in Judges 19 (see Masenya 2003:99), John 8 should first be read in the context of women as images of God to reduce the damage done to women.

In agreement with Fowler (1991:4), it should be said that the characteristic that most distinguishes human beings (males and females) from all other creatures is the issue of the image of God. According to Genesis, humanity was made in God's image and it exists in both sexes and does not permit us to set women aside when it comes to a full understanding of the nature of this image (Borreson 1986:27). MacGrath (1992:214) is correct when indicating that the creation order of God was violated during the fall so that now people are looking at things from the perspective of the fall. Even if we understand the Biblical message about the 'suitable helper' (Gen.2:18) when reading books and listening to those who preach about it in different churches, many people still fail to give this concept its true meaning, hence they think that because women were created second according to the second creation story, it means they were created for and to be objects of men. This view is influenced by the corruption that entered man during the fall, seeing as it was not like that before. Moltman (1984:11) makes a good point in believing that the starting point for an individual is to know that the dignity of man has its roots in the fact that every human being (women included) is an image of God.

\section{The role of the Church}

The Church must not shrink from teaching about the sinfulness and the consequences of sexual relationships outside marriage. This is why Van der Walt (2003:257) emphasises that sexual intercourse without trust is like playing with fire and can only bring seeming happiness, because it is nothing other than mutual exploitation and abuse. It is the duty of the Church to refute and correct the thinking of many people on arguments that condone and support premarital sexual intercourse, including when the man has to be sure whether his fiancée can bear children and the use of contraceptives which prevent unexpected pregnancy to make sexual sin holy. (Kyomo \& Selva 2004:38). Both within and outside the Church we should try to reach out to people through workshops, indaba gatherings, wedding preaching, premarital counselling sessions and other means to indicate to the people that sexual behaviour was meant from the beginning for married people only. According to Posel (2008:47), the Church is able to change the way how it talks about sex by strongly advocating sexual purity.

The Church through its prophetic voice should also advocate that the government should also impose stiffer penalties for sexual offences and make them a priority. People need to understand that seeing women as objects is another form of abuse. Stack et al. (2004:86) indicate that the Church can help individuals to have strong ties with religion which will also help them to have stronger marriages that helps to avoid the impure sexual thinking because the weak and unhappy marriages often expose people to these sex-related issues.

Waruta and Kinoti (2000:132) argue that women are not objects but subjects who should be treated with respect and honour. It is the Church's responsibility to transmit the message that liberates men from a wrong understanding of women. A liberating message for both men and women regarding sexual matters is important. Men need to be afflicted for the views of seeing women as objects. We must afflict the oppressor and support the afflicted in liberating the victims of oppression (Baloyi 2009:330). The Church and society need to empower women economically as a means of liberating them. Women can be empowered by helping them in seeking employment, encouraging them start small business and starting community projects (Koons \& Anthony 1991:134).

\section{CONCLUSION}

The reduction of women to mere sex objects as illustrated by the growing number of sexual offences in our country should become a matter of urgent concern, not only for the Commission for Gender Equality, but also for every responsible citizen of both sexes. We cannot become a community with a good name in the international media if the reduction of these sexual offences does not become a priority in all spheres of life, that is, in the home, in the workplace and in schools. There is a clear indication that most of the sexual immorality and sex scandals that are growing so fast in our country are rooted in the way men behave towards women, especially the issue of viewing women as mere objects of men. It is true that this behaviour has been cultivated culturally, but it has been fostered by the media and advertisements which make it easier for men to portray women as objects of sex. It is our responsibility as citizens of this country to engage watchdog bodies to inform Broadcasting Complaints Committee of South Africa on advertisements that promote the idea of seeing our mothers and sisters as sexual objects. 


\section{REFERENCES}

Baloyi, M.E., 2001, 'Counselling Christian Shangaans on choosing a marriage partner', MA thesis, Potchefstroom.

Baloyi, M.E., 2009, Patriarchal structures, a hindrance to women's right, VDM Publishing Company, Saarbrucken.

Baloyi, M.E., 2010, 'Lobolo in the African community: a critical study', In die Skriflig, 44(3), 1-21.

Berkhof, L., 1988, Systematic Theology, Oxford, Banner of Truth Trust.

Borreson, K.E., 1986, Subordination and equivalence. The nature and role of women in Augustine and Thomas Aquinas, Kok Pharoas Publishing House, Kampen.

De Bruyn, P.J., 1993, The ten commandments, Varia Publishers, Midrand.

Dreyer, J.S., 2009, 'Holistic pastoral ministry and the challenge of violence against women', paper presented at the Joint Conference of Academic societies in the fields of religion and theology, Academy of Practical Theology, Stellenbosch, 22-26 June 2009, n.p.

Fowler, S., 1991, A Christian voice among students and scholars. Potchefstroom, IRS.

Gigaba, M., 2008, Speech delivered at the Budget Vote 4, National Assembly, Cape Town, June 10, viewed 14 November 2008, from http://www.info.gov.za/speeches/2008/08061111451002. htm

Groothuis, R.M., 1994, Women caught in the conflict. The culture war between traditionalism and feminism, Baker Books, Grand Rapids.

Kimathi, G., 1994, Your marriage and family, Wetenskaplike bydraes of the PU for CHE, Series F2 no. 58, Potchefstroom, IRS.

King, U., 1989, Women and spiritualitity. Voices of protest and promise, Macmillan Education, London.

Kofon, N.E., 1992, Polygamy in pre-christian Bafut and New Moral Theological Perspectives, Peter Lang, New York.

Koons, C. \& Anthony, M., 1991, Single adult passages. Uncharted stories, Baker, Grand Rapids.

Kyomo, A.A. \& Selvan, S.G., 2004, Marriage and family in African Christianity, Acton Publishers, Nairobi.

Lebacqz, K., 1998, Love your Enemy: Sex, Power and Christian Ethics, in Jersild, PT (eds.), Moral issues and Christian Response, pp. 69-78, Fort Worth, Harcourt Brace College Publishers.

Le Roux, E., 2009, 'Pornography: human right or human rights violation?', paper presented at the Joint Conference of Academic Societies and Theology, Academy of Practical Theology, Stellenbosch, 22-26 June 2009, n.p.

Louw, D.J., 2009, 'Human sexuality in an eschatological perspective: Towards an aesthetics of human embodiment and erotic sensuality in practical theology', Journal of practical theology in South Africa, 24(1), 89-114.

MacGrath, A.E., 1992. Bridge building-communicationg. Christianity effectively, Intervarsity Press, Leicester.
Maluleke, T.S. \& Nadar, S., 2002, 'Breaking the covenant of violence against women' Journal of theology for Southern Africa 114, (Nov) 5-17.

Manala, M.J., 2005, 'An Afro-Christian ministry to people living with HIV/AIDS In South Africa' HTS Theological Studies 61(93), 897-914.

Masenya (ngwana' Mphahlele), M., 2003, 'Sacrificing female bodies at the alter of male privilege: Bosadi (womanhood) reading of Judges 19', Journal of theology and religion in Africa 27(1), 98-122.

Masenya (ngwana' Mphahlele), M., 2005, 'The Bible, HIV/AIDS and African-South African women: A Bosadi (Womanhood) perspective', Studia Historiae Ecclesiasticae, June 2005, vol. XXX1, no. 1, pp. 187-201.

Mbiti, J.S., 1990, African religions and philosophy, London, Heinemann.

Mbiti, J.S., 1991, Introduction to African religion, 2nd edn., Heinemann Publishers, Sandton.

Metuh, E.I., 1987, Comparative studies of African traditional religions, Claverianum Press, Ibadan.

Mpumelelo, M., 'CGE blasts misuse of women in ads' City Press, 13 November, p. 8.

Moltman, F., 1984, On human dignity, Great Britain, SCM Press.

Mokgotho, N.J., 2004, 'Pastoral care to women and children who have been raped and abused by men infected with HIV/ AIDS', thesis, University of Pretoria, South Africa.

Mugambi, J.N.K. \& Magesa, L., 1990, 'The church in African Christianity', Innovative Essays in Ecclesiology, Nairobi, Initiatives Ltd.

Nyirongo, L., 1997, Gods of Africa or God of the Bible? Potchefstroom, IRS.

Pule, S., 2002, 'Minister's daughter raped inside the church', City Press, 08 December, p. 4.

Posel, D., n.d., 'Getting the national talking about sex: reflections on the politics and nation-building in post-apartheid South Africa', unpublished manuscript, viewed 19 November 2008, from http://wiserweb.wits.ac.za

SABC Munghana Lonene Radio News 2009, 29 Oct. 05h45

Sengani, C., 2003, 'Sexual offences in Limpopo', paper read at Police Road show, Mukhomi village (Outside Giyani), 22 March.

Stack, S., Wasserman, I. \& Kern, R., 2004, 'Adult social bonds and use of internet pornography' Social science quarterly $85(1), 75-88$

Sunday Sun, 2005, 24 July, p. 31.

Thiam, A., 1986, Black sisters, speak out: feminism and oppression in black Africa, Pluto, London.

Van der Walt, B.J., 2003, Understanding and rebuilding Africa. From disperation today to expectation for tomorrow, Institute for Contemporary Christianity in Africa, Potchefstroom.

Van der Walt, B.J., 1998, The Bible as an eye opener on the position of women, IRS, Potchefstroom.

Waruta, D.W. \& Kinoti, H.K., 2000, Pastoral care in African Christianity, Nairobi, Acton Publishers. 